\title{
Peran Kompetensi Sebagai Variabel Intervening Hubungan Pembelajaran Organisasi \& Motivasi Spiritual Terhadap Kinerja Dosen dan Karyawan (Studi Pada IAIN Pekalongan)
}

\author{
Singgih Setiawan ${ }^{1}$, \\ Fakultas Ekonomi Bisnis Islam, Institut Agama Islam Negeri (IAIN) Pekalongan \\ singgih.setiawan@iainpekalongan.ac.id \\ Nafilah $^{2}$ \\ Fakultas Ekonomi Bisnis Islam, Institut Agama Islam Negeri (IAIN) Pekalongan \\ nafilsyukron@gmail.com
}

\begin{abstract}
Abstrak Penelitian ini bertujuan untuk menguji pengaruh Pembelajaran Organisasi dan Motivasi Spiritual Terhadap Kinerja Dosen dan Karyawan. Disamping itu, penelitian ini juga bertujuan untuk menguji peran Kompetensi sebagai variabel intervening. Untuk menguji variabel tersebut, peneliti memilih Dosen dan Karyawan di IAIN Pekalongan sebagai objek penelitian.

Penelitian dilakukan dengan metode menyebarkan kuisioner kepada 100 Dosen dan Karyawan di IAIN Pekalongan. Pengambilan Sampel penelitian menggunakan teknik Random Sampling. .

Hasil Penelitian menunjukkan bahwa Pembelajaran Organisasi dan Motivasi Spiritual berpengaruh positif signifikan terhadap Kinerja Dosen dan Karyawan pada IAIN Pekalongan. Sedangkan Kompetensi sebagai variabel intervening memperkuat pengaruh Pembelajaran Organisasi dan Motivasi Spiritual terhadap Kinerja Dosen dan Karyawan pada Institut Agama Islam Negeri (IAIN) Pekalongan.
\end{abstract}

Kata Kunci : Kompetensi, Pembelajaran Organisasi, Motivasi Spiritual, Kinerja

\section{PENDAHULUAN}

Sumber daya manusia merupakan salah satu unsur pelaksana dalam kegiatan organisasi yang bertugas dan bertanggung jawab menjalankan kegiatan-kegiatan operasional organisasi. Pengembangan Sumber Daya Manusia (SDM) dalam organisasi harus ditangani secara serius. Pengelolaan Sumber Daya Manusia yang baik akan berdampak pada kestabilan organisasi dan upaya pencapaian tujuan dan sasaran organisasi itu sendiri. Sumber daya manusia merupakan salah satu faktor penting dalam suatu organisasi, karena mereka yang melakukan aktivitas perusahaan serta mengembangkan perusahaan itu sendiri . Oleh karena itu faktor sumber daya manusia harus dikelola dengan baik agar dapat memberikan hasil yang optimal bagi perusahaan. Seorang karyawan dituntut tekun dalam bekerja, cekatan, memiliki keahlian dan kemampuan dalam melaksanakan tugas

Keberhasilan suatu organisasi sangat dipengaruhi oleh kinerja karyawannya. Apabila kinerja karyawan baik, maka hasil yang dicapai juga baik, namun sebaliknya apabila kinerja karyawan tidak baik maka hasil yang diperoleh juga tidak akan baik sehingga tujuan yang diinginkan oleh organisasi tidak dapat tercapai dengan maksimal. Untuk itu perlu perhatian dari pimpinan kantor untuk memenuhi kebutuhan personil, agar kinerja karyawan baik. Kinerja karyawan yang baik tentunya sangat diharapkan oleh semua organisasi atau perusahaan. Semakin banyak karyawan yang mempunyai kinerja tinggi, maka produktivitas secara keseluruhan akan meningkat sehingga organisasi atau perusahaan akan dapat bertahan dalam persaingan global. Kinerja karyawan dapat diketahui atau dinilai berdasarkan kemampuan teknik dalam bekerja sehingga karyawan tersebut akan memiliki pengalaman dan pelatihan sebelum bekerja (Rivai,2009). 
Salah satu aspek pengembangan SDM yang sangat penting diperhatikan adalah Pembelajaran Organisasi yang akan berdampak pada peningkatan Kinerja Karyawan. Kontribusi karyawan bagi organisasi sangat dominan, karena karyawan adalah penghasil kerja bagi organisasi. Setiap pekerjaan dalam organisasi selalu dilaksanakan oleh karyawan. Berhasil tidaknya suatu organisasi ditentukan oleh unsur manusia yang melakukan pekerjaan sehingga perlu adanya Pembelajaran Organisasi.

Karyawan adalah salah satu elemen terpenting dalam sebuah perusahaan, maka Motivasi Spiritual dan Kompetensi karyawan merupakan hal penting dalam upaya peningkatan kinerja karyawan. Perusahaan melakukan banyak cara dalam merangsang motivasi spiritual kerja karyawan, misalnya dengan memberikan dorongan berupa dorongan fitrah manusia untuk memenuhi kebutuhan ruhaniah seperti mengadakan siraman rohani di lingkungan kerja.

Kompetensi atau competency adalah kemampuan untuk melaksanakan suatu tugas/pekerjaan yang didasari atas pengetahuan, keterampilan dan sikap sesuai dengan unjuk kerja yang di persyaratkan.Kompetensi bagi beberapa profesi menjadi persyaratan penting dalam menjalankan kerangka dan tujuan organisasi.Masalah kompetensi itu menjadi penting, karena kompetensi menawarkan suatu kerangka kerja organisasi yang efektif dan efisien dalam mendayagunakan sumbersumber daya yang terbatas.

Ada beberapa penelitian yang meneliti mengenai variabel tersebut diantaranya : Kurniawan (2012), Hendrawan (2018) menemukan bahwa semua Pembelajaran Organisasi berpengaruh positif dan signifikan terhadap Kompetensi dan Basori (2013) serta Hasan etc (2017) menemukan bahwa semua Pembelajaran Organisasi berpengaruh positif dan signifikan terhadap Kinerja Karyawan, Hilmi (2018) dan Suparno (2007) menemukan bahwa Motivasi berpengaruh positif secara signifikan terhadap Kompetensi.

Shofwa (2013), Fasochah (2013) menyatakan bahwa Motivasi Spiritual berpengaruh positif secara signifikan terhadap Kinerja Karyawan, tetapi Motivasi Spiritual berpengaruh negatif secara siginifikan terhadap Kinerja Karyawan jika melalui mediasi Spiritual Leadership.

Berdasarkan fenomena yang ada di lapangan, untuk mewujudkan Institusi yang sehat dan maju, perlu faktor yang paling utama yaitu tenaga kerja atau karyawan dan dosen merupakan hal yang terpenting karena dosen dan karyawan merupakan pemakai dan penggerak serta penentu segala aktivitas yang ada di dalam institusi lembaga pendidikan. Sehingga peneliti tertarik untuk meneliti fenomena ini, dengan judul penelitian "Peran Hubungan Pembelajaran Organisasi \& Motivasi Spiritual dengan Kompetensi Sebagai Variabel Intervening Terhadap Kinerja (Studi Pada IAIN Pekalongan).

Tujuan dilaksanakan penelitian ini adalah :

1. Untuk mengetahui pengaruh Pembelajaran Organisasi terhadap Kompetensi pada Dosen dan Karyawan IAIN Pekalongan

2. Untuk mengetahui Motivasi Spiritual terhadap Kompetensi pada Dosen dan Karyawan IAIN Pekalongan

3. Untuk mengetahui Kompetensi terhadap Kinerja pada Dosen dan Karyawan IAIN Pekalongan

4. Untuk mengetahui Pembelajaran Organisasi terhadap Kinerja pada Dosen dan Karyawan IAIN Pekalongan melalui Kompetensi

5. Untuk mengetahui Motivasi Spiritual terhadap Kinerja pada Dosen dan Karyawan IAIN Pekalongan melalui Kompetensi

\section{Landasan Teori Pembelajaran Organisasi}

Proses pembelajaran menemukan adanya kemauan untuk menanggapi perubahan (Hartanto, 1995), ini menunjukkan adanya semangat untuk terus memperbarui diri. Senge (1990) sebagai pencetus organisasi pembelajaran, yang dimaksud pembelajaran organisasi adalah, organisasi yang dapat memotivasi orang-orang di dalamnya secara berkelanjutan, meningkatkan kapasitas mencapai 
apa yang dicita-citakan, mengembangkan pola pikir baru, mengutarakan aspirasi kolektif secara bebas dan para anggota organisasi belajar bersama berkelanjutan. Definisi pembelajaran organisasi secara universal belum pernah ditemukan. Devinisi pembelajaran organisasi lebih cenderung kepada kegiatan yang berorentasi tindakan ( action oriented ) dan fokus pada implementasi yang merupakan sebuah pendekatan konkret dan menentukan.(Dill, 1999; T sang, 1997).

Pembelajaran organisasi merupakan salah satu bentuk pengembangan organisasi yang didasarkan pada pengetahuan. Menurut Taylor pembelajaran organisasi merupakan kesempatan yang diberikan kepada pegawai sehingga organisasi lebih efisien.(Luthans, 1995; 173)(3). Sementara Garvin mendevinisikan pembelajaran organisasi sebagai keahliahn organisasi untuk menciptakan, memperoleh, mennginterpretasikan, mentransfer dan membagi pengetahuan, yang bertujuan memodifikasi perilakunya untuk menggambarkan pengetahuan dan wawasan baru.

Pembelajaran Organisasi oleh Robbin dimaknai sebagai suatu organisasi yang terus berupaya mengembangkan kemampuan kapabilitas pada lingkungan yang berubah.Menurut Fiol dan Lyles (1985), organisasi pembelajar adalah proses guna mengembangkan tindakan lewat pengetahuan dan pengertian yang lebih baik. Hubber (1991), menyatakan bahwa organisasi pembelajar adalah sebuah entitas yang belajar apabila terjadi pemrosesan informasi dan merupakan perilaku potensial yang memungkinkan terjadinya perubahan. Agryris (1977), mendefinisikannya sebagai sebuah proses deteksi dan koreksi kesalahan (error). Levitt dan March (1988), menyatakan bahwa organisasi terlihat sebagai sebuah proses belajar karena proses pengambilan keputusan dalam sejarah terhadap rutinitas yang mengarahkan perilaku. Stata (1989), melihat bahwa proses pembelajaran terjadi lewat penjabaran dimana didalamnya ada pengetahuan dan model mental, serta bangunan pengetahuan dan pengalaman. Secara kesluruhan merupakan memori organisasi. Pembelajaran organisasi berkaitan dengan perilaku yangdiharapkan dari masing-masing individu dalam organisasi dan tidak ada dua orang individu yang perilakunya sama dalam lingkungan pekerjaan tertentu (Kondealkar:2007).

\section{Motivasi Spiritual}

Menurut Malayu Hasibuan, kata motivasi berasal dari bahasa Latin movere yang berarti dorongan atau menggerakkan. Sedangkan apabila dikaitkan dengan manajemen sumber daya manusia, maka motivasi ini mempersoalkan tentang cara untuk dapat mengarahkan daya dan potensi bawahan agar mau bekerja secara produktif sehingga berhasil mencapai standar yang sudah ditetapkan mencapai tujuan yang sudah ditentukan. Sedangkan menurut Berelson dan Steiner yang dikutip oleh Abdul Mursi menyebutkan bahwa istilah motivasi merupakan kondisi internal dari seorang individu yang dapat melahirkan kekuatan, kegairahan dan dinamika serta pada akhirnya mampu mengarahkan dan membentuk pola tingkah laku individu yang bersangkutan

Ada beberapa teori motivasi konvensional yang disampaikan oleh Sondang Siagian antara lain: (1) Teori Motivasi Douglass Mc Gregor, menyimpulkan bahwa bahwa para manajer menggolongkan para bawahannya pada dua kategori berdasarkan asumsi tertentu. (2) Teori Motivasi Frederick Herzberg atau "Teori Motivasi dan Higiene". kesimpulannya para karyawan dapat dibagi menjadi dua golongan besar : mereka yang termotivasi oleh factor-faktor intrinsic, yaitu daya dorong yang timbul dari dalam diri masing-masing dan factor ekstrinsik, yaitu pendorong yang datang dari luar diri seseorang, terutama dari organisasi tempatnya berkarya.(3) Teori "ERG", teori ini mengatakan bahwa, manusia memunyai tiga kelompok kebutuhan inti (core need), yang disebutnya Eksistensi, Hubungan dan Pertumbuhan (Existence, Relatedness, and Growth - ERG).

Berkaitan dengan aspek pemenuhan kebutuhan manusia,dalam Islam, kebutuhan manusia itu dibagi menajadi kebutuhan jasmani (lahiriyah) dan kebutuhan rohani (bathiniyah), maka tingkah laku manusia tidak hanya dimotivasi untuk memenuhi kebutuhan jasmani, tetapi juga tingkah laku manusia dimotivasi untuk memenuhi kebutuhan rohani/spiritual. Dorongan-dorongan yang memotivasi tingkah 
laku manusia untuk memenuhi kebutuhan rohani inilah yang kemudian disebut dengan motivasi spiritual. Selanjutnya, Anshari menjelaskan bahwa motivasi spiritual seorang muslim terbagi menjadi tiga: motivasi akidah, motivasi ibadah dan motivasi muamalat. Motivasi akidah adalah keyakinan hidup, yaitu pengikraran yang bertolak dari hati.

Jadi, motivasi akidah dapat ditafsirkan sebagai motivasi dari dalam yang muncul akibat kekuatan akidah tersebut. Ibadah merupakan tata aturan Illahi yang mengatur hubungan ritual langsung antara hamba Allah dengan Tuhannya yang tata caranya ditentukan secara rinci dalam Al Qur'an dan Sunnah Rasul. Sedangkan motivasi ibadah merupakan motivasi yang tidak pernah dilakukan oleh orang yang tidak memiliki agama, seperti sholat, doa, dan puasa. Jika dikaitkan dengan kegiatan bekerja, ibadah masih berada dalam taraf proses, sedangkan output dari ibadah adalah muamalat. Muamalat merupakan tata aturan Illahi yang mengatur hubungan manusia dengan sesama manusia dan manusia dengan benda atau materi. Motivasi muamalat ini berarti mengatur kebutuhan manusia seperti: kebutuhan primer (kebutuhan pokok), sekunder (kesenangan) dengan kewajiban untuk dapat meningkatkan kinerja dan kebutuhan primer (kemewahan) yang dilarang oleh Islam

\section{Kompetensi}

Kompetensi berasal dari kata "competency" merupakan kata benda yang menurut Powell (1997:142) diartikan sebagai 1) kecakapan, kemampuan, kompetensi 2) wewenang. Kata sifat dari competence adalah competent yang berarti cakap, mampu, dan tangkas.Pengertian kompetensi ini pada prinsipnya sama dengan pengertian kompetensi menurut Stephen Robbin (2007:38) bahwa kompetensi adalah "kemampuan (ability) atau kapasitas seseorang untuk mengerjakan berbagai tugas dalam suatu pekerjaan, dimana kemampuan ini ditentukan oleh 2 (dua) faktor yaitu kemampuan intelektual dan kemampuan fisik.(14)( Kumpulan artikel news- google, 17 pebruari 2019)

Kompetensi menurut Spencer dan Spencer dalam Palan 2007 adalah sebagai karakteristik dasar yang dimiliki individu yang berhubungan secara kausal dalam memenuhi kriteria yang diperlukan dalam menduduki suatu jabatan.(12)

Menurut Keputusan Kepala Badan Kepegawaian Negeri Nomor: 46A tahun 2003, tentang pengertian kompetensi adalah :kemampuan dan karakteristik yang dimiliki oleh seorang Pegawai Negeri Sipil berupa pengetahuan, keterampilan, dan sikap perilaku yang diperlukan dalam pelaksanaan tugas jabatannya, sehingga Pegawai Negeri Sipil tersebut dapat melaksanakan tugasnya secara profesional, efektif dan efisien.(15)kristina nugi keran, Pengaruh Motivasi Kerja, Kompetensi, Dan Kompensasi Terhadap Kinerja Karyawan Di Yayasan Bintang Timur Tangerang , jkt, 2012

Kompetensi adalah suatu kemampuan untuk melaksanakan atau melakukan suatu pekerjaan atau tugas yang dilandasi atas keterampilan dan pengetahuan serta didukung oleh sikap kerja yang dituntut oleh pekerjaan tersebut (Wibowo, 2010).

Wibowo (2010) menyatakan bahwa kompetensi merupakan landasan dasar karakteristik orang dan mengindikasikan cara berperilaku atau berpikir, menyamakan situasi, dan mendukung untuk periode waktu cukup lama. Terdapat 5 (lima) karakteristik atau komponen kompetensi yaitu : 1. Motif, adalah sesuatu yang secara konsisten dipikirkan atau diinginkan orang yang menyebabkan tindakan motif mendorong, mengarahkan dan memilih prilaku menuju tindakan atau tujuan tertentu. 2. Sifat, adalah karakteristik dan respon yang konsisten terhadap situasi dan informasi. 3. Konsep Diri, adalah sikap, nilai-nilai atau citra diri seseorang, percaya diri merupakan keyakinan orang bahwa mereka dapat efektif, dalah hampir setiap situasi adalah bagian dari konsep diri setiap orang. 4. Pengetahuan, adalah informasi yang dimiliki orang dalam bidang spesifik, pengetahuan merupakan kompetensi yang komplek, skor pada tes pengetahuan sering gagal memprediksi prestasi kerja karena gagal mengukur pengetahuan dan keterampilan dengancara yang sebenarnya dipergunakan dalam pekerjaan. 5 . 
Keterampilan, adalah kemampuan mengerjakan tugas fisik atau mental tertentu, kompetensi mental atau keterampilan kognitif termasuk berfikir analitis dan konseptual.(17) Ilman Ataunur, Eny Ariyanto, Penagaruh Kompetensi dan Pelatihan terhadap Kinerja Karyawan PT. Adaro Energy TBk,Telaah Bisnis, Vol 16, No.2, Desember 2015

\section{Kinerja}

Suatu hal yang sangat penting dalam mencapai tujuan perusahaan adalah kinerja karyawan. kinerja atau prestasi kerja adalah hasil kerja secara kualitas dan kuantitas yang dicapai oleh seorang karyawan dalam melaksanakan tugasnya sesuai dengan tanggung jawab yang diberikan kepadanya.Kinerja adalah merupakan suatu proses tentang bagaimana pekerjaan berlangsung untuk men-capai hasil kerja. Kinerja atau prestasi kerja adalah sebagai hasil atau apa yang keluar (outcomes) dari sebuah pekerjaan dan kontribusi mereka pada organisasi.Kinerja merupakan suatu fungsi dari motivasi dan kemampuan. Untuk menyelesaikan tugas atau pekerjaan seseorang sepatutnya memiliki derajat kesediaan dan tingkat kemampuan tertentu. Kinerja merupakan perilaku yang nyata yang ditampilkan setiap orang sebagai prestasi kerja yang dihasilkan oleh karyawan sesuai dengan perannya dalam perusahaan (Rivai, 2010). (19)Ilman Ataunur, Eny Ariyanto, Penagaruh Kompetensi dan Pelatihan terhadap Kinerja Karyawan PT. Adaro Energy TBk,Telaah Bisnis, Vol 16, No.2, Desember 2015

Adapun pendapat Wirawan (2009:6) juga mengemukakan bahwa kinerja karyawan merupakan hasil sinergi dari sejumlah faktor. Faktor-faktor tersebut adalah 1. Faktor lingkungan internal organisasi yang terdiri atas visi, misi, dan tujuan organisasi, kebijakan organisasi, bahan mentah, teknologi (robot, sistem produksi, dan sebagainya), strategi organisasi, sistem manajemen, kompensasi, kepemimpinan, modal, budaya organisasi, iklim organisasi, dan teman sekerja. 2. Faktor lingkungan eksternal yang terdiri dari, kehidupan ekonomi, politik, budaya dan agama masyarakat serta kompetitor. 3. Faktor internal karyawan atau pegawai yang terdiri atas, bakat dan sifat pribadi, kreativitas, pengetahuan dan keterampilan, kompetensi, pengalaman kerja, keadaan fisik, dan keadaan psikologi. (20)Eka Suhartini, Pengaruh Kompetensi Terhadap Kinerja Pegawai (Studi Perbandingan Antara Fakultas Ekonomi Dan Bisnis Islam Dan Fakultas Syariah Dan Hukum Uinam) .

\section{Pengertian Kinerja}

Sutrisno (2013) mengungkapkan bahwa kinerja atau prestasi kerja adalah sebagai hasil kerja yang telah dicapai seseorang dari tingkah lakukerjanya dalam melaksanakan aktivitas kerja. Pengertian lain oleh Mangkunegara (2012) yang mengungkapkan kinerja karyawan adalah hasil kerja secara kualitas dan kuantitas yang dicapai oleh seseorang karyawan dalam melaksanakan tugasnya sesuai dengan tanggung jawab yang diberikan kepadanya.Menurut Wibowo (2007) kinerja merupakan implementasi dari rencana yang telah disusun. Implementasi kinerja dilakukan oleh sumber daya manusia yang memiliki kemampuan, kompetensi, motivasi dan kepentingan. Bagaimana organisasi menghargai dan memperlakukan sumber daya manusianya akan mempengaruhi sikap dan perilakunya dalam menjalankan kinerja.

\section{METODOLOGI PENELITIAN}

\section{Jenis Penelitian dan Sumber Data}

Jenis penelitian ini adalah penelitian kuantitatif yang menghasilkan penemuan-penemuan yang dicapai dengan menggunakan prosedur-prosedur statistik. Jenis data yang digunakan dalam penelitian ini adalah data primer dan sekunder. Data primer yaitu data yang diperoleh dari responden melalui kuisioner, sedangkan data sekunder yaitu data yang diperoleh dari catatan, buku, laporan perusahaan dan laporan pemerintah. 


\section{Definisi Operasional Variable Pembelajaran Organisasi (X1)}

Learning organization adalah suatu perusahaan yang menyadari pentingnya pelatihan dan pengembangan yang terkait dengan kinerja berkelanjutan dan mau mengambil tindakan yang tepat (Mondy, 2008). Dengan indikator :

1. Disiplin Personal Mastery

2. Disiplin Berbagi Visi

3. Disiplin Mental Model

4. Disiplin Pembelajaran Tim

\section{Motivasi Spiritual (X2)}

Motivasi Spiritual adalah motivasi dari dalam yang muncul akibat kekuatan akidah tersebut. Ibadah merupakan tata aturan Illahi yang mengatur hubungan ritual langsung antara hamba Allah dengan Tuhannya yang tata caranya ditentukan secara rinci dalam Al Qur'an dan Sunnah Rasul. Dengan indikator sebagai berikut :

1. Tingkat Pengamalan Doa

2. Sholat

3. Puasa

\section{Kompetensi (Y1)}

Stephen Robbin (2007) bahwa kompetensi adalah "kemampuan (ability) atau kapasitas seseorang untuk mengerjakan berbagai tugas dalam suatu pekerjaan, dimana kemampuan ini ditentukan oleh 2 (dua) faktor yaitu kemampuan intelektual dan kemampuan fisik. Dengan indikator sebagai berikut :
1. Motives
2. Traits
3. Knowledge
4. Skill

\section{Kinerja (Y2)}

Kinerja karyawan adalah kemampuan seseorang melakukan sesuatu untuk mencapai tujuan yang telah ditetapkan menurut ukuran yang berlaku tidak hanya berwujud hasil fisik saja tetapi meliputi kemampuan kerja, disiplin, tanggung jawab, kesetiaan, kejujuran dan kerja sama yang dilakukan selama periode waktu tertentu sesuai dengan wewenang dan tanggung jawab masingmasing dalam mencapai tujuan organisasi. (Robbins,2006). Dengan Indikator sebagai berikut :

1. Human Performance

2. Ability

3. Inisiatif

4. Kemandirian

\section{Populasi dan Sampel}

Jenis populasi dalam penelitian ini adalah populasi infinit dengan anggota atau elemen populasi adalah semua Dosen dam Karyawan IAIN Pekalongan Dalam penelitian ini menggunakan metode Random Sampling yaitu teknik untuk menentukan sampel penelitian dengan cara random/acak dengan beberapa pertimbangan tertentu.

Menghitung ukuran sampel yang dilakukan dengan menggunakan teknik Slovin. Adapun penelitian ini menggunakan rumus Slovin karena dalam penarikan sampel, jumlahnya harus representative agar hasil penelitian dapat digeneralisasikan dan perhitungannya pun tidak memerlukan tabel jumlah sampel, namun dapat dilakukan dengan rumus dan perhitungan sederhana. 
Jumlah populasi dalam penelitian ini adalah sebanyak 1450 karyawan, sehingga presentase kelonggaran yang digunakan adalah $10 \%$ dan hasil perhitungan dapat dibulatkan untuk mencapai kesesuaian. Maka untuk mengetahui sampel penelitian, dengan perhitungan sebgai berikut:

$$
\begin{aligned}
\mathbf{n}= & 1450 \\
& \begin{array}{l}
1+1450(10)^{2} \\
\mathbf{n}= \\
15,5
\end{array}=93,5 ; \text { disesuaikan oleh peneliti menjadi } 100 \text { responden. }
\end{aligned}
$$

Berdasarkan perhitungan diatas sampel yang mejadi responden dalam penelitian ini di sesuaikan menjadi sebanyak 100 orang atau sekitar $10 \%$ dari seluruh total Dosen dan Karyawan IAIN Pekalongan, hal dilakukan untuk mempermudah dalam pengolahan data dan untuk hasil pengujian yang lebih baik. Sampel yang diambil berdasarkan teknik probability sampilng; simple random sampling, dimana peneliti memberikan peluang yang sama bagi setiap anggota pupulasi (karyawan) untuk dipilih menjadi sampel yang dilakukan secara acak tanpa memperhatikan strata yang ada dalam populasi itu sendiri.

\begin{tabular}{|c|c|c|c|c|c|c|}
\hline \multirow{2}{*}{\multicolumn{2}{|c|}{ Model }} & \multicolumn{2}{|c|}{$\begin{array}{l}\text { Unstandardized } \\
\text { Coefficients }\end{array}$} & \multirow{2}{*}{$\begin{array}{c}\text { Standardized } \\
\text { Coefficients } \\
\text { Beta }\end{array}$} & \multirow[b]{2}{*}{$\mathrm{t}$} & \multirow[b]{2}{*}{ Sig. } \\
\hline & & B & Std. Error & & & \\
\hline \multirow[t]{3}{*}{1} & (Constant) & 7.205 & 3.210 & & 2.245 & .027 \\
\hline & $\begin{array}{l}\text { Pembelajaran } \\
\text { Organisasi }\end{array}$ & .253 & .071 & .328 & 3.584 & .001 \\
\hline & Motivasi Spiritual & .237 & .060 & .362 & 3.956 & .000 \\
\hline
\end{tabular}

\section{HASIL PENELITIAN}

\section{Hasil Uji Regresi Coefficients $^{\mathrm{a}}$}

a. Dependent Variable: Kinerja

Sumber : Data primer yang diolah (2019) sebagai berikut :

Berdasarkan tabel 4.16, persamaan regresi linier berganda pada penelitian ini adalah

Kinerja Pegawai $=7,205+0,253 \mathrm{X} 1+0,237 \mathrm{X} 2$

Persamaan regresi diatas dapat dijelaskan sebagai berikut:

Konstanta sebesar 7,205 artinya jika tidak ada pengaruh terhadap Kinerja, maka nilai Kinerja sebesar 7,205 


\section{Uji Hipotesis}

Uji hipotesis ini digunakan untuk menguji kebenaran suatu pernyataan secara statistic dan menarik kesimpulan apakah menerima atau. menolak pernyataan tersebut.

\section{Coefficients $^{\mathrm{a}}$}

\begin{tabular}{|c|c|c|c|c|c|}
\hline \multirow[b]{2}{*}{ Model } & \multicolumn{2}{|c|}{ Unstandardized Coefficients } & \multirow{2}{*}{$\begin{array}{c}\text { Standardized Coefficients } \\
\text { Beta }\end{array}$} & \multirow[b]{2}{*}{$\mathrm{t}$} & \multirow[b]{2}{*}{ Sig. } \\
\hline & B & Std. Error & & & \\
\hline 1 (Constant) & 6.558 & 4.064 & & 1.614 & .110 \\
\hline Pembelajaran Organisasi & .429 & .089 & .416 & 4.805 & .000 \\
\hline Motivasi Spiritual & .295 & .076 & .336 & 3.887 & .000 \\
\hline
\end{tabular}

a. Dependent Variable: Kompetensi

Berdasarkan tabel 4.16, persamaan regresi linier berganda pada penelitian ini adalah sebagai berikut :

Kinerja Pegawai $=6.558+0,429 \mathrm{X} 1+0,295 \mathrm{X} 2$

Persamaan regresi diatas dapat dijelaskan sebagai berikut:

Konstanta sebesar 7,205 artinya jika tidak ada pengaruh terhadap Kinerja, maka nilai Kinerja sebesar 7,205

\section{Uji Mediasi}

Uji mediasi ini adalah sebagai untuk menjelaskan sebuah hubungan variable perantara dengan variable bebas.

\section{Coefficients $^{\mathrm{a}}$}

\section{Unstandardized Coefficients Standardized Coefficients}

\begin{tabular}{lr|r|r|r|r}
\multicolumn{1}{l}{ Model } & \multicolumn{1}{c|}{ B } & Std. Error & Beta & \multicolumn{1}{c|}{ t } & Sig. \\
\hline 1 (Constant) & 4.868 & 2.915 & & 1.670 & .098 \\
\hline Pembelajaran Organisasi & .100 & .070 & .130 & 1.427 & .157 \\
\hline Motivasi Spiritual & .132 & .058 & .201 & 2.293 & .024 \\
\hline Kompetensi & .356 & .070 & .477 & 5.105 & .000 \\
\hline
\end{tabular}

Dependent Variable: Kinerja

Berdasar hasil analisis diperoleh hasil yang signifikan dengan hubungan perantara

\section{SIMPULAN}

Dari hasil analisis dan pembahasan pada bab sebelumnya, maka dapat disimpulkan sebagai berikut. Pembelajaran Organisasi berpengaruh terhadap Kompetensi ditunjukkan dengan nilai $P$-value yang 
signifikan sehingga Pembelajaran Organisasi berpengaruh positif signifikan terhadap Kompetensi di Institut Agama Islam Negeri Pekalongan. Motivasi Spiritual berpengaruh terhadap Kompetensi ditunjukkan dengan nilai $P$-value yang signifikan sehingga Motivasi Spiritual berpengaruh positif signifikan terhadap Kompetensi di Institut Agama Islam Negeri Pekalongan. Kompetensi berpengaruh terhadap Kinerja ditunjukkan dengan nilai $P$-value yang signifikan sehingga Kompetensi berpengaruh positif signifikan terhadap Kinerja di Institut Agama Islam Negeri Pekalongan. Pembelajaran Organisasi berpengaruh terhadap Kinerja ditunjukkan dengan nilai $P$-value yang signifikan sehingga Pembelajaran Organisasi berpengaruh positif signifikan terhadap Kinerja di Institut Agama Islam Negeri Pekalongan. Motivasi Spiritual berpengaruh terhadap Kinerja ditunjukkan dengan nilai $P$ value yang signifikan sehingga Motivasi Spiritual berpengaruh positif signifikan terhadap Kinerja di Institut Agama Islam Negeri Pekalongan. Pembelajaran Organisasi dan Motivasi Spiritual berpengaruh terhadap Kinerja ditunjukkan dengan nilai $P$-value yang signifikan sehingga Pembelajaran Organisasi dan Motivasi Spiritual berpengaruh positif signifikan terhadap Kinerja di Institut Agama Islam Negeri Pekalongan. Pembelajaran Organisasi, Motivasi Spiritual dan Kompetensi berpengaruh Terhadap Kinerja ditunjukkan dengan nilai $P$-value yang signifikan sehingga Pembelajaran Organisasi, Motivasi Spiritual dan Kompetensi berpengaruh positif signifikan terhadap Kinerja di Institut Agama Islam Negeri Pekalongan.

\section{DAFTAR PUSTAKA}

Alizar Hasan. 2017. Pengaruh Kemampuan Pembelajaran Organisasi Terhadap Kinerja Industri Menengah Bidang Pangan di Kota Padang. Jurnal Ekonomi dan Bisnis. Semarang

Andi Hendrawan. 2018. Pengembangan Kompetensi UMKM dengan Pembelajaran Organisasi Jurnal Ekonomi dan Bisnis. Jakarta

Asep Kurniawan, 2012. Pengaruh Kemmpuan Pembelajaran Organisasi Terhadap Kompetensi, Tingkat Diversifikasi dan Kinerja STAI Swasta di Wilayah III Cirebon. Jurnal Ekonomi dan Bisnis. Jakarta

Atep Hilman Hilmi, 2018. Pengaruh Motivasi Guru Terhadap Kompetensi Guru dalam Mewujudkan Mutu Pembelajran Pendidikan Agama Islam. Jurnal Ekonomi dan Bisnis. Jakarta

Diana Pramudya Wardhani, 2017. Pengaruh Kompetensi Terhadap Kinerja Pegawai Pada Dinas Perhubungan, Komunikasi dan Informatika Kabupaten Mamuju Utara. Tesis

Fasochah, 2011. Spiritual Leadership Memoderasi Pengaruh antara Motivasi Spiritual Keryawan Terhadap Kinerja Religius ( Studi Kasus Di Kawasan Industri Kecil dan Menngah Kab.Kendal. Jurnal Ekonomi dan Bisnis. Semarang

Luthans, F. 1998. Organizational Behaviour. 8th End,, Boston : Irwin McGrawhill.

Mohammad Imam Basori. 2015. Pengaruh Learning Organization Terhadap Kinerja Organisasi dengan Budaya Organisasi Sebagai Variabel Moderasi Pada Perpustakaan Universitas Airlangga. Jurnal Ekonomi dan Bisnis. Semarang

Rivai, Veithzal . 2003. Performance Appraisal. Jakarta: PT. Raja Grafindo Persada. Grafindo Persada. 2004.Manajemen Sumber Daya Manusia Untuk Perusahaan. Jakarta: PT. Raja 
2005.Manajemen Sumber Daya Manusia Untuk Perusahaan Dari Teori Ke Praktik. Edisi 1. Jakarta: PT. Raja Grafindo Persada.

Robbins, S.P. 1996. Perilaku Organisasi, Konsep, Kontroversi danAplikasi. Alih Bahasa : Hadyana Pujaatmaka. Edisi Keenam. Jakarta:Penerbit PT.Bhuana Ilmu Populer. 2001, Perilaku Organisasi jilid satu,Jakarta: Gramedia Pustaka 2003. Perilaku Organisasi jilid dua. Jakarta: Indeks Kelompok Gramedia.

2, Jakarta : Salemba.

2008. Perilaku Organisasi, Alih Bahasa Diana Angelica. Edisi Keduabelas. Jilid 1 dan

Suparno, 2007. Pengaruh Motivasi Kerja dan Kepemimpinan Situasional Kepala Sekolah Terhadap Kinerja Guru SMP Negeri di Kec.Pemalang Kab,Pemalang. Tesis.

Yoiz Shofwa, 2013. Pengaruh Motivasi Spiritual dan Kepemimpinan Spiritual Terhadap Kinerja Religius Dosen dan Karyawan STAIN Purwokerto. Jurnal Ekonomi dan Bisnis. Jakarta

Yuliana,2017. Pengaruh Kompetensi dan Motivasi Kerja Terhadap Kinerja Karyawan Perusahaan Pada PT.Haluan Star Logistic. Tesis 